\title{
鉄筋コンクリート部材の主筋の座屈性状に関する研究 BUCKLING BEHAVIORS OF STEEL BARS IN R/C COLUMNS
}

\author{
加藤大 $^{*}$ \\ Daisuke KATO
}

\begin{abstract}
This paper reports on the evaluation method of the axial buckling strains of longitudinal steel bars in reinforced concrete columns, subjected to axial load. Two series of experiments were conducted. In series 1, buckling behaviors of bars subjected to compressive axial load only and those subjected to cyclic load reversals, were compared. In series 2 , twenty six $15 \mathrm{~cm}$ square column specimens, confined by various reinforcement, were subjected to compressive axial load only, in order to evaluate buckling strains. The analytical model was developed, taking into account the effects of the diameter of hoops and longitudinal bars and spacing of hoops.
\end{abstract}

Keywords : reinforced concrete, buckling of steel bar, hoop confinement 主筋の座屈, 座屈防止筋, 帯筋の拘束効果

\section{1. 序}

鉄筋コンクリート $(\mathrm{RC})$ 造部材内の主筋が早期の座 屈をすることなく十分に圧縮力を負担するためには，帯 筋による拘束が不可欠である。現在までに，帯筋により 拘束された主筋の座屈性状を実験的に評価する研究1) 31 や主筋の座屈を部材の靬性の決定要因として検討する研 究1) 81 が行われている。 $\mathrm{RC}$ 部材内の主筋の座屈挙動を 評価する際の問題点としては，i）実験におりる座屈点 の定義, ii ) 実験で得られた主筋の軸歪度が部材長に沿っ て不均一であるための影響の処理，iii）一般に主筋の座 屈は帯筋数区間にまたがって生じるためにモデルでの座 屈長さの決め方, iv）繰返し載荷の影響の評価, 等があ り問題が非常に複雑になっている。

筆者は，鉄筋コンクリート部材において主筋の必要限 界圧縮軸昰度が与えられた場合に，それを確保するため の帯筋の配筋方法, すなわち, 帯筋の径, 間隔, 形状等 を求める方法を開発することを目的に，正方形帯筋によ り拘束された角柱試験体の一方向単軸圧縮実験を行い, 主筋の軸方向応力度-歪度関係を大略的に評価するモデ ルを作成し，実験とモデルを比較してその妥当性を検討 し，報告してきだ91,10)。特に，前述したi）～iii）の問 題点を解決することにも重点をおいている。

本報告では，ますす，問題点iv）に挙げた主筋の座屈に 対する繰り返しの影響を把握するために行った単調載荷 と繰返し載荷の比較実験について報告する。次に，文献 9），10）で提案した座屈モデルを実験データを参考にし
て簡略化した座屈時軸昰度推定式について報告する。な お, 文献 9)，10）における単調軸圧縮実験は一端ピン 他端固定支持の加力方法を用いていたので, 改めて両端 固定支持の加力方法で実験を行った。なお, 繰返し実験 の結果の詳細は文献 11）で既に報告してある。

\section{2. 主筋の座屈の繰り返しによる影響}

\section{1 実験概要}

主筋の座屈性状を解明する際には, 繰返し荷重を受け ることにより単調荷重のみ受ける場合に比べ主筋の座屈 が早期に生じることを評価する必要がある。そこで, 同 一の配筋 (主筋・帯筋) を持つ角柱試験体の単調之繰返 しの載荷実験を行い, 絽返し載荷を受ける主筋の軸方向 応力度-軸方向昰度関係の評価を行った。なお，主筋の みの挙動を抽出するために, 繰り返し・単調のいずれに おいても主筋なしの試験体についても実験を行った。

表一1に試験体の諸元および使用した鉄筋とコンク リートの性質を示す。実験は 2 シリーズからなる。ジ)ー ズ'A は帯筋間隔の一区間が主筋の座屈長さになる(以下, 一区間座屈と呼ぶ）上うに設計したシリーズで，2 区間 以上での座屈を防止するのに十分な帯筋として D 10 鉄 筋を間隔 $93 \mathrm{~mm}$ で配筋したシリーズである。シリーズ B は主筋の座屈長さが複数の帯筋間隔にわたる（以下， 多区間座屈と呼ぶ) ように設計したジリーズで, 帯筋と してD 6 鉄筋を間隔 $35 \mathrm{~mm}$ で配筋したシリーズである。 各シリーズにおいて，主筋を有する試験体（D13 主筋

\footnotetext{
* 新潟大学工学部建設学科 助教授. 工博
} Assoc. Prof., Dept of Architecture and Civil Engineering, Faculty of Engineering, Niigata Univ., Dr. Eng. 
を 4 本) と主筋のない試験体（施工上最小限の主筋が必 要なため $\phi 4$ 鉄筋を 4 本配筋) を 2 体ずつ製作し，それ ぞれ単調と繰返じの載荷を行った。また，比較のため各 シリーズで無拘束の試験体を作製した。試験体名の A ・ $\mathrm{B}$ は头験のシリーズ名を 4 ・0 は D 13 主筋の本数を, $\mathrm{C} \cdot \mathrm{M}$ は繰返し載荷あるいは単調載荷を意味する。P は無拘束試験体である。

単調載荷用および主筋なしの繰返し載荷用の計 8 体 （試験体番号 $1 \sim 8$ ) は $15 \mathrm{~cm} \times 15 \mathrm{~cm} \times 53 \mathrm{~cm}$ の直方体 試験体とした。繰返し載荷用試験体 2 体（試験体番号 9, 10）は直方体試験体と同一の $15 \mathrm{~cm} \times 15 \mathrm{~cm}$ の柱の上下 に引張力載荷用の基礎を設置した I 型試験体とした。な お, I 型試験体の柱部分の測定区間の配筋は, 同シリー ズの直方体試験体と同一である。図一1にシリーズ A

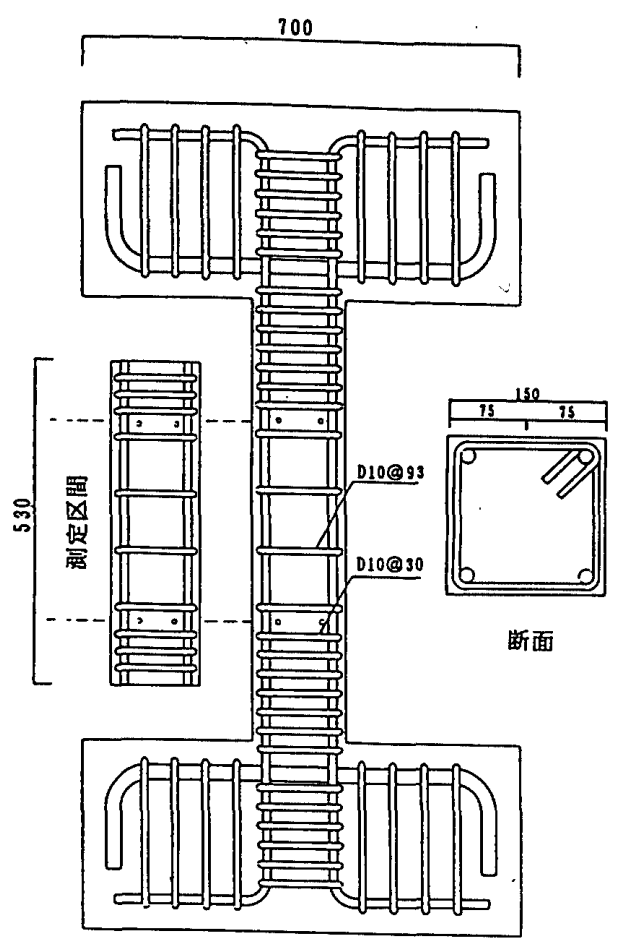

図一-1＼cjkstart試験体配筋図

(繰返し実験シリーズのAシリーズ)
の主筋を有する試験体の配筋図を示す。なお，かぶりは ないものとして計画したが,施工上かぶりが必要なため,

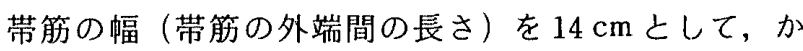

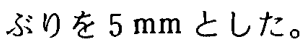

図一2(a)(b) に単調および繰返しの加力装籄図を示 す。単調載荷は両端固定支持とし, 繰返し載荷は, 圧縮 力は両端固定支持で, 引張力は両端ピンの左右のジャッ キにより与えた。繰返しを受ける試験体の載荷嗄歴は引 張力, 圧縮力の順に軸歪度で $0.2,0.4,0.6,1.0 \%$ を 1 回ずつ,さらに, $2.0 \%$ を 2 回繰り返した後に, 王縮 方向に加力した。また，主筋のない試験体の繰返し載荷 は圧縮力の加力と除荷のみの繰り返し（片押し）とした。 軸歪度の測定区間は図一1の破線に示すように角柱・I 型試験体とも共通とし, 前面と後面で 2 箇所ずつの計 4 箇所に設置した電気式変位計を用いて, 柱部分中央位置 の間隔 $324 \mathrm{~mm}$ ( $\mathrm{A}$ シリーズ), $350 \mathrm{~mm}$ (Bシリーズ) で測定した。また，主筋の歪ゲージは带筋間隔が 70 $\mathrm{mm}$ 以上のものでは各帯筋間隔の中間点に表裏で 2 枚添

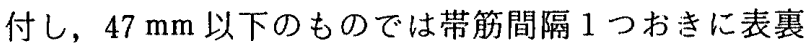
1 組のゲージを添付した。
軸力 3

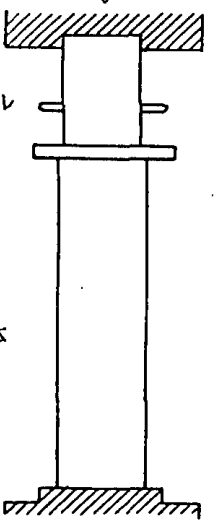

（a）単調載荷・片押し載荷

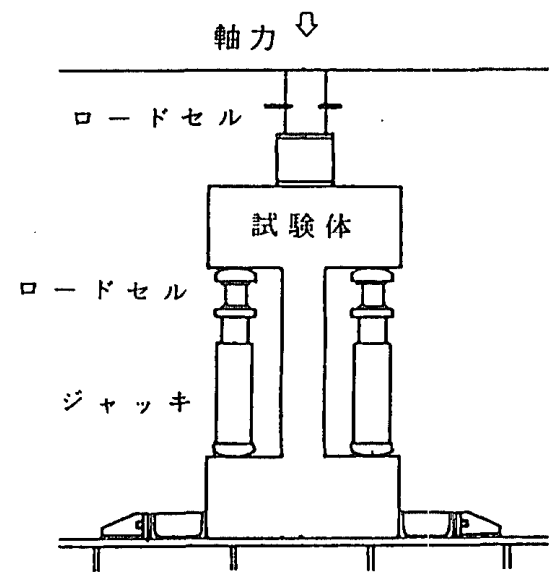

（b）繰返し載荷
図一2 加力装置図

表一1 繰返し実験シリーズ試験体の諸元の実験結果

\begin{tabular}{|c|c|c|c|c|c|c|c|c|c|c|c|c|c|c|}
\hline $\begin{array}{l}\dot{y} \\
y \\
1 \\
x^{*}\end{array}$ & 番 & 試跧体名 & $\begin{array}{l}\text { 主胼径 } \\
\text { と形状 }\end{array}$ & $\begin{array}{l}\text { 帯筋径 } \\
\text { と形状 }\end{array}$ & $\begin{array}{c}\text { 带䈂 } \\
\text { 間隔 } \\
\text { 喵 }\end{array}$ & $\begin{array}{l}\text { 全断面 } \\
\text { 帯胼比 } \\
\text { P日 \% }\end{array}$ & $\begin{array}{l}\text { コ } \\
\text { 体積比 } \\
\rho \quad \% \\
\end{array}$ & $\begin{array}{l}\text { 主筋降 } \\
\text { 伏地力 } \\
\text { 度 } \sigma y \\
t / \mathrm{cm}^{*}\end{array}$ & $\begin{array}{l}\text { 主筋破 } \\
\text { 断応力 } \\
\text { 度 } \sigma \mathrm{m} \\
\mathrm{t} / \mathrm{cm}^{2}\end{array}$ & $\begin{array}{c}\text { 帯筋降 } \\
\text { 伏庆力 } \\
\text { 度 } \sigma \text { wy } \\
t / \mathrm{cm}^{2} \\
\end{array}$ & $\begin{array}{l}y^{\prime} y^{*}- \\
\text { 強度 } \\
\sigma_{\mathrm{g}} \\
\mathrm{kg} / \mathrm{cm}^{2} \\
\end{array}$ & $\begin{array}{l}\text { 最大 } \\
\text { 耐力 } \\
\text { tonf } \\
\end{array}$ & $\begin{array}{l}\text { 最終座屈 } \\
\text { 長さ mm } \\
\text { (帯筋間 } \\
\text { 隔倍数) } \\
\end{array}$ & $\begin{array}{c}\text { 破壊領 } \\
\text { 域長さ } \\
\text { mm } \\
\end{array}$ \\
\hline \multirow{5}{*}{ A } & 1 & A $4 \mathrm{M}$ & $4-D 13$ & 2-D10 & 93 & 1.02 & 2.18 & 3.63 & 5.22 & 3.59 & 268 & 73.9 & $93(1)$ & 155 \\
\hline & 2 & $A O M$ & $4-\phi 4$ & $2-D 10$ & 93 & 1.02 & 2.18 & 6.35 & 6.74 & 3.59 & 268 & 56.3 & - & 147 \\
\hline & 3 & $\mathrm{AOC}$ & $4-\phi 4$ & 2-D10 & 93 & 1.02 & 2.18 & 6.35 & 6.74 & 3.59 & 268 & 59.7 & - & 128 \\
\hline & 4 & A P & - & - & - & - & - & - & - & - & 268 & 46.7 & - & - \\
\hline & 9 & A $4 \mathrm{C}$ & 4-D13 & 2-D10 & 93 & 1.02 & 2.18 & 3.63 & 5. 22 & 3.59 & 268 & 82.5 & $93(1)$ & 140 \\
\hline \multirow{5}{*}{ B } & 5 & B 4 M & 4-D13 & $2-D 6$ & 35 & 1.22 & 2.61 & 3.63 & 5.22 & 3.55 & 254 & 81.9 & $140(4)$ & 225 \\
\hline & 6 & B O M & $4-\phi 4$ & 2-D6 & 35 & 1.22 & 2.61 & 6.35 & 6.74 & 3.55 & 254 & 65.1 & - & 135 \\
\hline & 7 & BO C & $4-\phi 4$ & 2-D6 & 35 & 1.22 & 2.61 & 6.35 & 6.74 & 3.55 & 254 & 69.6 & - & 216 \\
\hline & 8 & B P & - & - & - & - & - & - & - & - & 254 & 55.9 & - & - \\
\hline & 10 & $B 4 C$ & A-D13 & 2-D6 & 35 & 1.22 & 2.61 & 3. 63 & 5.22 & 3.55 & 254 & 85.2 & $140(4)$ & 169 \\
\hline
\end{tabular}




\section{2 実験結果の概要}

表一1の後半に各試験体の最大耐力, 最終座屈長さ, 座屈長さの帯筋間隔に対する倍数，および，破壊領域の 長さの実験值を示した。なお，座屈長さは実験中目視に より測定し，また，破壊領域は実験終了後コア部分が圧 壊している領域と定義して測定した。

図一3(a)（b) に主筋のないもので単調載荷と繰返し 載荷を受ける試験体の軸方向力-測定区間平均軸䄳度関 係を示す。繰返し力は片押しであるが，両加力方法によ る軸方向力-軸歪度関係の包絡線の違いはほとんよ゙観察 されなかった。

図一4（a)（b）は主筋を有する試験体の単調載荷之繰 返し載荷を受ける試験体の軸方向力-測定区間平均軸歪 度関係をシリーズ別に示したものである。いずれのシ

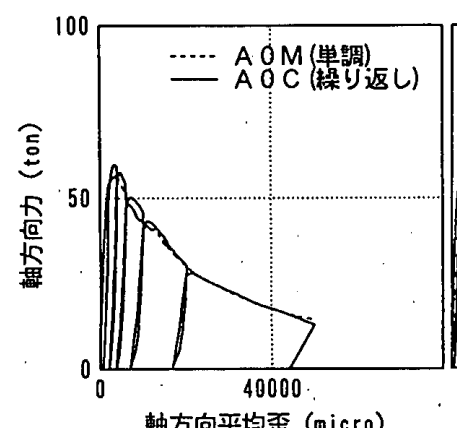

(a) A シリーズ

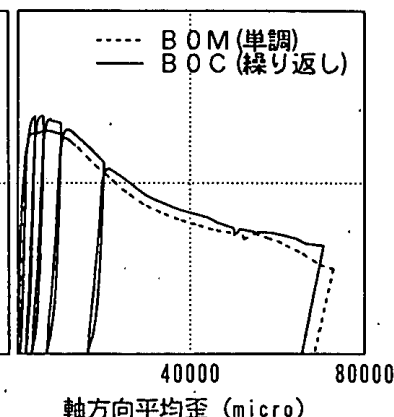

(b) Bシリーズ
图一3 主筋のない試験体の単調載荷之繰返し載荷の比較

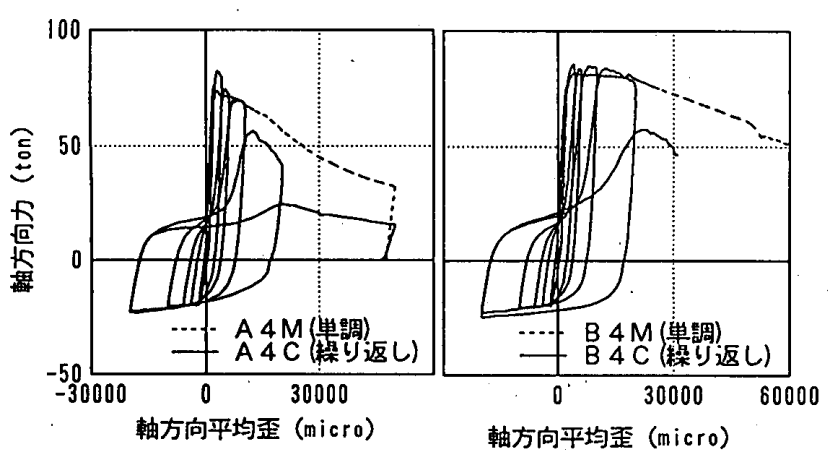

(a) Aシリーズ

(b) Bシリーズ

図一４主筋を有する試験体の単調載荷と繰返し載荷の比較
リーズでも低歪領域では繰返し載荷による影響は少ない が，高歪領域で繰返し載荷を受ける試験体の軸方向耐力 が単調載荷を受ける試験体に比べ低下していくことが分 かる。主筋のない試験体の実験結果より，繰返しによる コンクリート部分の耐力への影響はほとんどないと考え ることができるため, 主筋の挙動が繰返し載荷試験体の 耐力の低下の要因となっていることが推測される。

2.3 主筋の応力度-歪度関係の繰り返しによる影響

2.3.1 主筋の負担軸力の抽出方法

本節では，主筋の負担軸力を以下の仮定 i ), ii ）の 下に推定する。すなわち，i）主筋を有する試験体とな い試験体のコンクリートの挙動は同一とする。ii）主筋 を有する試験体のコンクリートが引張力と圧縮力の繰返 し載荷を受ける場合の圧縮側の包絡線は片押しの繰返し 載荷を受けるコンクリートの包絡線と同一とする。なお， 上記の仮定の i ）については, 多区間座屈のものでは带 筋による拘束力が座屈した主筋を介して他の点から加わ るため, 厳密には成立しない。しかし, 全拘束力はほぼ 同程度であることを考虑しこの仮定を許容した。

以上の仮定により，単調載荷を受ける主筋の負担分は 同シリーズ内の主筋なしの単調荷重試験体の耐力を差し 引いて得られる。次に, 図一 5 に繰返し載荷試験体の主 筋の負担分の抽出の概念図を示す。まず，実験結果を各 サイクルごとに圧縮と引張の加力領域に分け（図-5 (a)), 圧縮加力方向は主筋を有する試験体とない試験体 の差を主筋の負担分, 引張加力方向の耐力はそのまま主 筋の負担分とし（図一5(b)); 抽出した結果を合わせた ものを各サイクルの主筋の負担軸力とする（図一5(c)）。 ただし，王縮加力方向の包絡線部分までの領域は，主筋 のない試験体では実験を行っていないため,コンクリー トの負担分は不明である。そこで，図一5(d) に示すよ うに圧縮再加力点から包絡線までは直線的に増加させ た。

一方，得られた主筋の測定区間平均軸昰度-軸方向応 力度関係は, 文献 9）之同様の方法で座屈した区間の軸 歪度一軸方向応力度関係に修正した。すなわち, 測定区 間全長のうち座屈長さ以外の部分の軸歪度は座屈長さ以

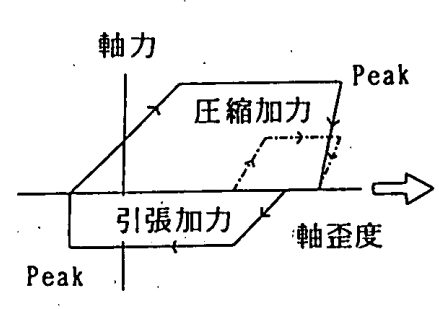

一主筋有り

主筋なし

（a）各サイクルの結果

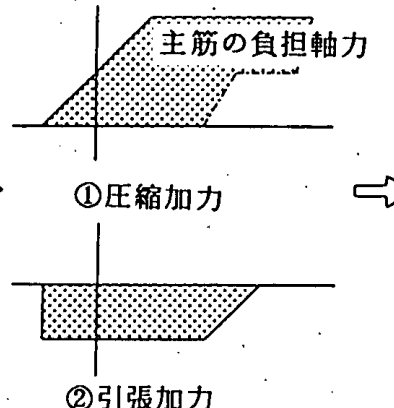

(2)引張加力

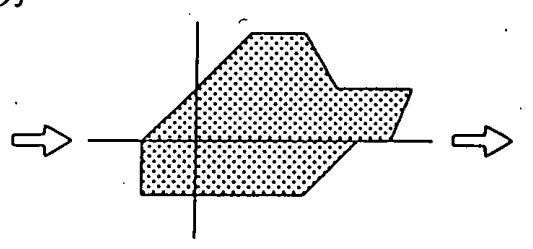

(c) 主筋の負担分

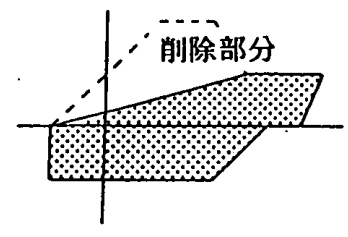

（d）主筋の負担分の修正

(b) 各方向の主筋の負担分

図一5 主筋の負担軸力の抽出概念図 


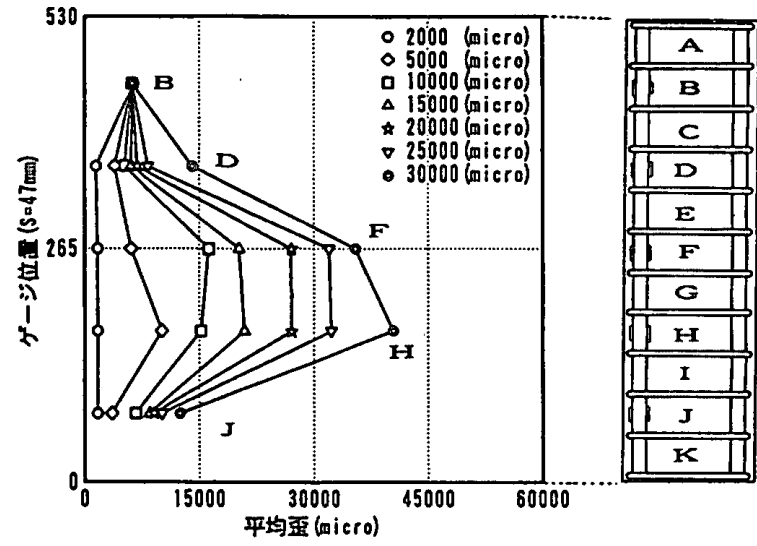

图一6 主筋霆ゲージ位置と歪度の分布（4D13D6S 47）

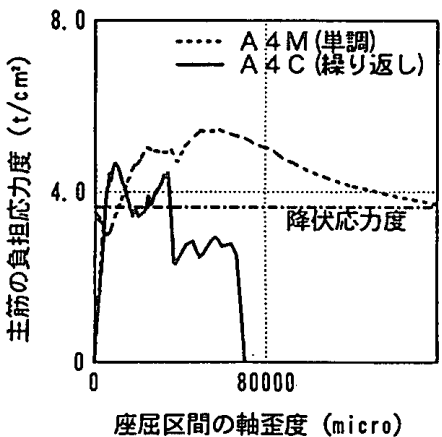

(a) $A$ シリーズ

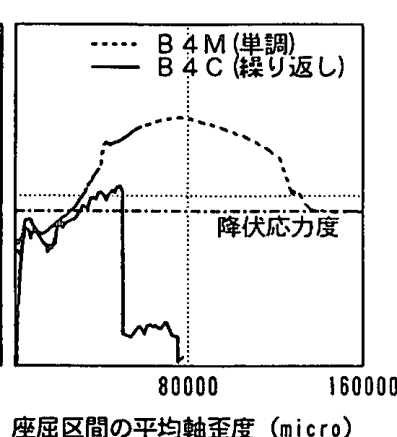

(b) Bシリーズ
図一7 主筋の負担分の繰返し載荷と単調載荷の比較（圧縮方向 包絡線）

外の部分に添付した歪ゲージによる主筋の歪度の平均と 仮定して，この部分を差し引くことにより求めた。図一 6 は3. で示す試験体 4D13D6S47 の主筋歪ゲージ位置 と測定された歪度の分布の例であり, 全測定区間の平均 歪度が 2000 30000.マイクロのいくつかの点について 示してある。この例では最終的に帯筋区間 $\mathrm{F}$ - H の 3 区間での座屈と判定されている。したがって，F〜H の 3 区間の軸歪度を修正された主筋の軸歪度とした。なお， $\mathrm{F}$ - H 33 区間以外の主筋の歪度は区間 B，D および J のゲージより得られた歪度の平均とした。なお, 引張歪 を受ける領域では全測定長さで均一な軸歪度になること からこの修正は行わない。

\section{3 .2 主筋の負担軸力の操り返しの影響}

本節では主筋の負担軸力の繰返し載荷による影響を評 価する。図一7(a) (b) は2.3.1で示した方法より抽出 した各サイクルの主筋の負担軸力を主筋の全断面積で除 して求めた主筋の応力度の内, 正加力領域の包絡部分の みを取り出して, 繰返し載荷を受けるものと単調載荷を 受けるものとをシリーズ別に比較したものである。図を みると繰り返しを受けるものは単調載荷のものに比べて かなり早期の段階で座屈により負担軸力が低減すること がわかる。

次に, 図一8(a)(b) は累積軸垔度の概念を導入して

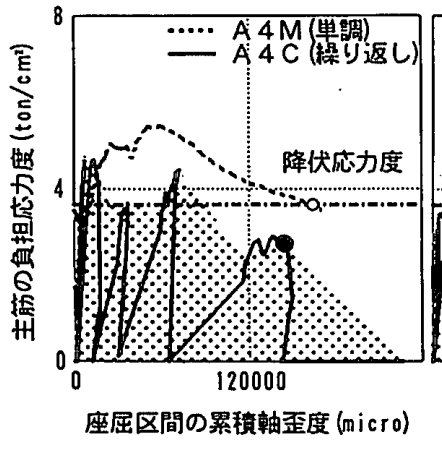

(a)

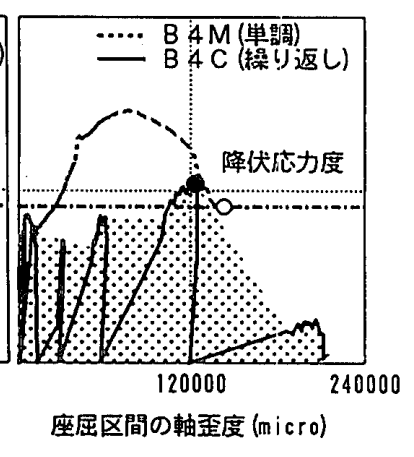

(b)
図一8 主筋の負担分の繰返し載荷と単調載荷の比較 (累積歪度)

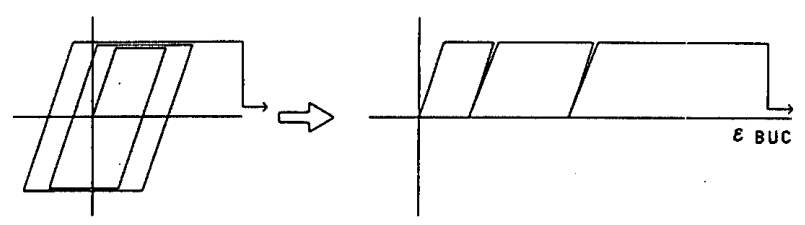

図一9座屈を考慮した主筋のモデル

繰返し載荷と単調載荷の実験結果をシリーズ別に比較し たものである。同図の実線は 2.3.1で示した方法を用い て得られた各サイクルの主筋の負担分の圧縮加力領域の 部分（図一5(b) の上半分）を各サイクル順に加算して いった累積軸昰度（図一9参照）を横軸にとって主筋の 負担分を示したものであり, その包絡領域を点影で示し てある。同図中の破線は単調載荷のものであるが，単調 載荷曲線における主筋の座屈点を耐力が歪硬化域に入っ た後に再び降伏軸力を下まわった点（図中の○）とし， また, 繰返し載荷曲線における座屈点を包絡線の耐力が 急激に低下する点と考えると, 単調載荷曲線の座屈点と 累積軸歪度を用いた繰返し載荷曲線の座屈点はおおむね 一致していると評価できる。なお，繰返し載荷曲線にお ける急激な耐力低下点とは前サイクルではほぼ降伏応力 度を維持していたのに, 次のサイクルでは応力度がほぼ 0 となる点と定義し，図中に黒丸で示した。

以上より，繰返し載荷試験体の主筋の応力媵-䄳度関 係は，概念図一 9 に示すように正加力時の軸方向歪度を サイクル順に加算した累積歪度が単調載荷を受ける主筋 の座屈歪度 $\left(\varepsilon_{B U C}\right)$ と等しくなった点で座屈するモデル で表現できることがわかる。またこれらは，鉄骨構造物

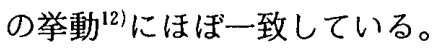

\section{3. 主筋の座屆の単調載荷実験}

\section{1 実験概要}

主筋の座屈モデルを考える際に，主筋の径のほかに拘 束帯筋の径と間隔が重要な因子となる。そこで，この観 点から主筋と帯筋の配筋法をパラメータにした実験を計 画した。表一 2 に計画した試験体名を主筋と帯筋の配筋 法別に示す。すなわち, 主筋の配筋法を 4 通り（内 1 つ は主筋のないものと考えている 4- $\phi 4)$, 帯筋の配筋法 
表一2 一方向実験シリーズの試験体名と材料強度

\begin{tabular}{|c|c|c|c|c|c|c|c|c|}
\hline & & \multicolumn{4}{|c|}{ 主 筋 の 配 筋 法 } & \multirow[b]{2}{*}{$\begin{array}{l}\text { 帯筋降伏 } \\
\text { 究力度 } \\
\left(\mathrm{kg} / \mathrm{cm}^{\prime}\right)\end{array}$} & \multirow[b]{2}{*}{ 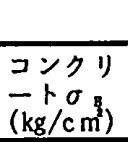 } & \multirow[b]{2}{*}{$\begin{array}{c}\text { 軸歪度 } \\
\text { 測定間隔 } \\
(\mathrm{mm})\end{array}$} \\
\hline & & $4-D 16$ & $4-D 13$ & $4-D 10$ & $4-\phi 4$ & & & \\
\hline 帯 & 2-D10-\$93. & 4D16D10S93 & $(\mathrm{A} 4 \mathrm{M})$ & 4D10D10S93 & $4 \phi 4 \mathrm{D} 10 \$ 93$ & 3590 & 285 & 324 \\
\hline 筋 & 2-D6-S70 & $4016 D 6 S 70$ & 4D13D6S70 & 4D10D6S70 & $4 \phi 4 D 6 S 70$ & \multirow{3}{*}{3550} & 254 & 300 \\
\hline の & $2-D 6-\$ 47$ & 4D16D6S47 & 4D13D6S47 & 4D10D6S47 & $4 \phi 4 D 6 S 47$ & & 251 & 360 \\
\hline 配 & $2-D 6-S 35$ & 4D16D6S35 & (B4M) & 4D10D6S35 & $4 \phi 4 D 6 S 35$ & & 244 & 350 \\
\hline 筋 & $2-\phi 4-\$ 47$ & $4 D 16 \phi 4 S 47$ & $4 D 13 \phi 4 S 47$ & $4 D 10 \phi 4 S 47$ & $4 \phi 4 \phi 4 S 47$ & \multirow{3}{*}{5940} & 260 & 360 \\
\hline \multirow[t]{2}{*}{ 法 } & $2-\phi 4-\$ 35$ & $4 D 16 \phi 4 S 35$ & $4013 \phi 4 S 35$ & $4 D 10 \phi 4 S 35$ & $4 \phi 4 \phi 4 S 35$ & & 256 & 350 \\
\hline & $2-\phi 4-\$ 23$ & $4 D 16 \phi 4 S 23$ & $4013 \phi 4 S 23$ & $4 D 10 \phi 4 S 23$ & $4 \phi 4 \phi 4 S 23$ & & 224 & 320 \\
\hline & $\begin{array}{l}\text { 主筋降伏底力 } \\
\text { 度 }\left(\mathrm{kg} / \mathrm{c} \mathrm{m}^{\prime}\right)\end{array}$ & 3490 & 3500 & 3860 & 5940 & & & \\
\hline & $\begin{array}{l}\text { 表筋破断它力 } \\
\text { 尊 }\left(\mathrm{kg} / \mathrm{cm}^{\prime}\right)\end{array}$ & 5070 & 5050 & 5330 & 6260 & & & \\
\hline
\end{tabular}

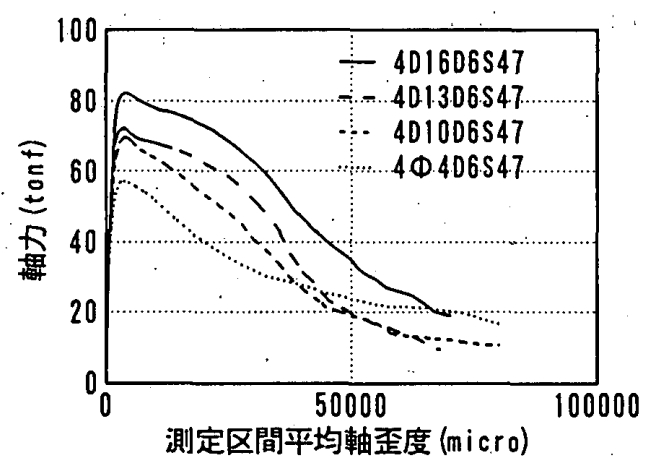

図一10 帯筋がD 6S47 シリーズの荷重-軸霆度曲線

を 7 通り想定し，計 28 体計画した。なお，そのうち 2 体は 2. 節で示した試験体 A 4MとB4Mに相当するので 実験は省略し, 実際には26体作製した。試験体の名前は, 例えば4D16D10S93は主筋にD16 を 4 本, 带筋に D 10 を用い帯筋間隔を $93 \mathrm{~mm}$ としたものを意味する。 なお，同図には使用した鉄筋とコンクリートの性質，お よび軸歪度の测定区間の間隔も示した。試験体の形状, 加力方法および測定方法は2. 節で示した単調加力シ リーズと全く同じである。

\section{2 実験結果およびその整理}

図一10に帯筋が D 6 で間隔 $47 \mathrm{~mm}$ のシリーズの軸方 向力-測定区間の平均軸歪度の関係を示す。これらの関 係を用いて 2. 節で示した方法により各試験体の主筋の 負担軸力を推定した。試験体 4D16D10S93および試験 体 4D16D6S47 の修正例を図一11(a)(b) に示す。図 中の点線は図一10の軸力の差を主筋の負担分としたも の，実線はさらに座屈区間の軸歪度に修正したものであ る。

図一11の修正結果をみると, 抽出された主筋の応力 度-歪度関係には降伏点がみられるが，この降伏応力度 は必ずしも引張試験から得られた降伏応力度（図中 1 点 鎖線参照）に達していない。これは主筋のある試験体と 主筋のない試験体の差をとるときの誤差であると考えら れる。しかし, 明確な降伏点がみられるので,この降伏

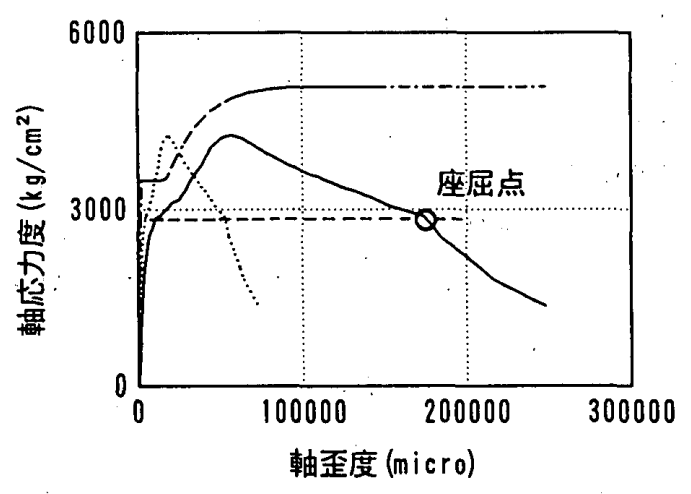

(a) 試験体 4 D 16D 10S 93

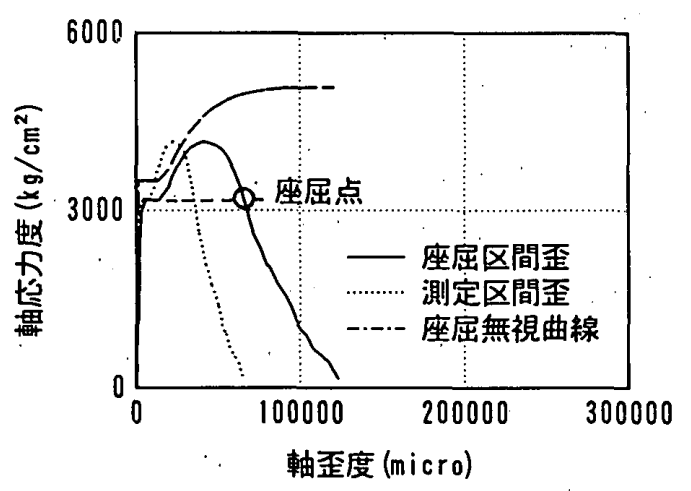

(b) 試験体 4D16D6S47

図一11＼cjkstart主筋の応力度の抽出と座屈点の定義

表一3一方向実験シリーズの座屈歪度のま之め

\begin{tabular}{|c|c|c|c|c|}
\hline & \multicolumn{3}{|c|}{ 主 筋 $の$ 配 筋 法 } \\
\hline & & $4-D 16$ & $4-D 13$ & $4-D 10$ \\
\hline 帯 & $2-D 10-S 93$ & $170000(1)$ & $164000(1)$ & $65000(1)$ \\
\hline 筋 & 2-D6-S70 & $45000(3)$ & $110000(2)$ & $42500(1)$ \\
\hline の & $2-D 6-S 47$ & 65000 (4) & 65000 & 60000 (3) \\
\hline 配 & $2-D 6-S 35$ & $50000(5)$ & $143000(4)$ & $125000 \quad(2)$ \\
\hline 筋 & $2-\phi 4-\$ 47$ & $42500(5)$ & $20000(4)$ & $27500(3)$ \\
\hline \multirow[t]{2}{*}{ 法 } & $2-\phi 4-\$ 35$ & $45000(6)$ & $55000(5)$ & 118000 \\
\hline & $2-\phi 4-\$ 23$ & $60000(7)$ & $60000(5)$ & $100000(3)$ \\
\hline
\end{tabular}

応力度を基本にして座屈点を定義した。すなわち，降伏 後に歪硬化域に入り, 再び降伏点に達した点を座屈点と した。図中の○が評価された座屈点となり，このときの 
軸歪度を座屈歪度 $\varepsilon_{B U C}$ とした。座屈歪度 $\varepsilon_{B U C}$ の実験值 を表一 3 にまとめた。同表には加力終了後に確認した座 屈区間 $N_{B}$ も（）で示してある。これは, 座屈長さが 帯筋間隔 $S$ の何倍であるかを示したものである。

\section{4. 主筋の座屈時の歪度 $\varepsilon_{B U C}$ の評価}

4.1 主筋の軸方向応力度-歪度関係のモデル化の概要

文献 9，10）で提案した帯筋により拘束された主筋の 軸方向応力度-歪度関係モデルの概念図を図-12(a) (b) に示す。まず，座屈は主筋が昰硬化域開始点（図一12(a) B点) までは生じないとした。次に，ある座屈区間 $\left(N_{B}\right.$ とおく）を仮定する。図一12(b) は $N_{B}=3$ の例であり， 座屈長さは帯筋間隔 $S$ を用いて $N_{B} \cdot S$ であるが，この とき中間の帯筋を無視して瞬間判性を用いて求めたオイ ラ一座屈応力度がそのときの主筋の応力度より小さく なった点を図一12(a) のC点とする。この点から座屈区 間 $N_{B}$ の座屈が始まるわけであるが，中間の帯筋が存在 するのでその挙動は図-12(a) の曲線 D-E-F のよう になり，実際の区間 $N_{B}$ の座屈の応力度-歪度関係の経 路は $\mathrm{C}-\mathrm{E}-\mathrm{F}$ をたどることになる。なお，C点を潜在 座屈開始点と呼ぶ。以上の経路を想定可能な座屈区間 $N_{B}$ についてそれぞれ求めることができ，実際の挙動は それらの最小値の包絡線をとることになる。ここで，文

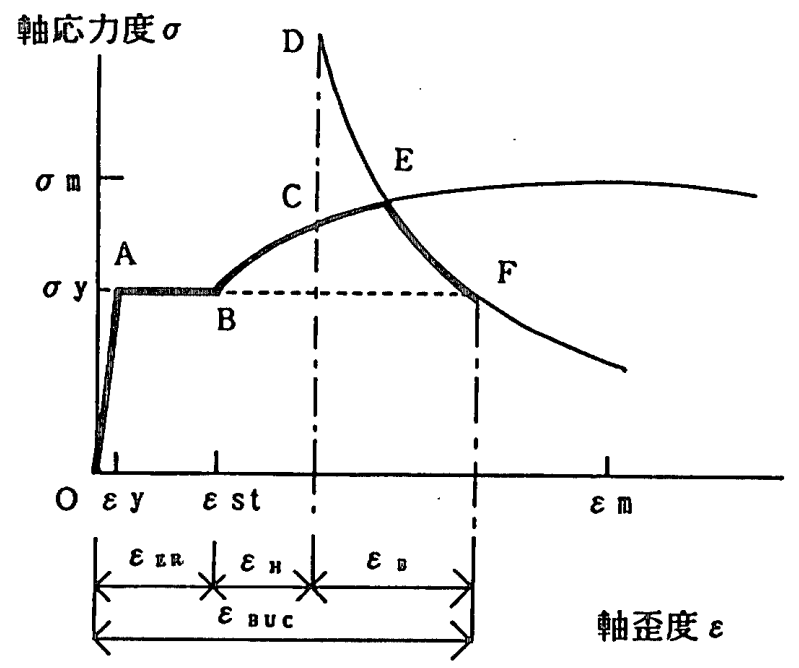

(a) 解析概念図

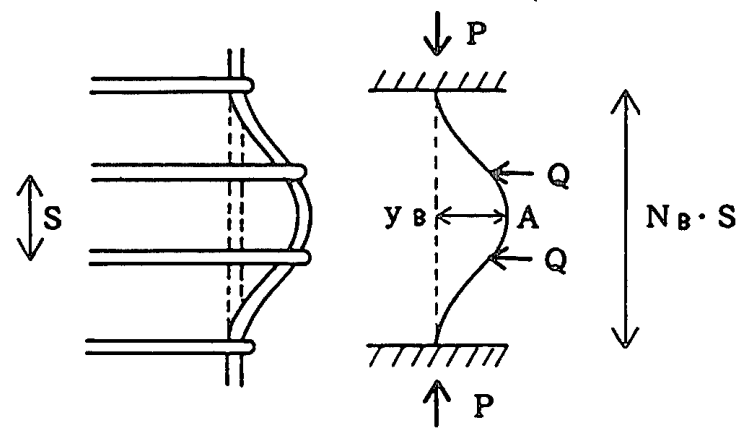

(b) 3 区間座屈のモデル

図一12 主筋の座屈モデル
献 9)，10）では古典的 Double Modulus Theory を用い て C 点を決定し, 座屈後の曲線 $\mathrm{D}-\mathrm{E}-\mathrm{F}$ は後述の式 （5）を提案している。また，座屈がない場合の主筋の 圧縮方向の軸方向応力度 $\sigma$-昰度 $\varepsilon$ 関係は以下の式で与 えた。なお，符号は王縮を正とする。

$$
\begin{aligned}
\sigma= & E s \cdot \varepsilon \quad\left(\leqq \sigma_{y}\right) \quad\left(0 \leqq \varepsilon<\varepsilon_{s t}\right) \\
= & \left\{1-\left(1-\frac{\varepsilon-\varepsilon_{s t}}{\varepsilon_{m}-\varepsilon_{s t}}\right)^{n}\right\} \cdot\left(\sigma_{m}-\sigma_{y}\right) \\
& +\sigma_{y} \quad\left(\varepsilon_{s t} \leqq \varepsilon \leqq \varepsilon_{m}\right) \\
& \left(n=E_{t} \cdot\left(\varepsilon_{m}-\varepsilon_{s t}\right) /\left(\sigma_{m}-\sigma_{y}\right)\right)
\end{aligned}
$$

ここで， $E_{s}$ は鉄筋ヤング係数， $\sigma_{y}$ は主筋降伏応力度, $\varepsilon_{y}$ は主筋降伏歪度 $\left(=\sigma_{y} / E_{s}\right), \varepsilon_{s t}$ は歪硬化開始時主筋 昰度 $\left(=10 \cdot \varepsilon_{y}\right), \sigma_{m}$ は主筋最大応力度, $\varepsilon_{m}$ は立筋最大 応力度時歪度 $\left(=10 \cdot \varepsilon_{s t}\right), E_{t}$ は歪硬化開始時鉄筋ヤン グ係数 ( $\left.=E_{s} / 30\right)$ ，である。

\section{2 座屈後の曲線の評価}

座屈による軸歪度であるが，図一12(b) のようには らみ曲線を正弦波形とするとその变形による幾何学的な 軸方向の縮み量 $\delta_{B}$ と歪度 $\varepsilon_{B}$ は以下の式で近似できる。

$$
\begin{aligned}
& \delta_{B}=\int_{0}^{x_{0}} d \delta=\int_{0}^{x_{0}} 1 / 2 \cdot(d y / d x)^{2} d x \\
& \varepsilon_{B}=\delta_{B} / x_{0}=\left(\left(\pi \cdot y_{0}\right) /\left(4 \cdot x_{0}\right)\right)^{2}
\end{aligned}
$$

ただし $y=y_{0} \cdot \sin \left(\pi \cdot x_{0} / 2 \cdot x\right)$

$y_{0}: 1$ 端固定他端自由支持の横変位で図-12(b)

$$
\text { では } y_{0}=y_{B} / 2
$$

$x_{0}: 1$ 端固定他端自由支持の座屈長さで図 -12

(b) では $x_{0}=N_{B} \cdot S / 4$

次に，軸方向応力度であるが，まず，鉄筋の終局時の 軸力ーモーメント関係を

$$
\begin{aligned}
& a_{x} \cdot\left(M / M_{p}\right)+\left(N / N_{\rho}\right)=1 \\
& \left(a_{x}=0.65 \text {, 適用範囲 }: N>0.5 \cdot N_{\rho}\right) \\
& N_{\rho}=a_{h} \cdot \sigma_{m}=\pi \cdot \phi_{h}{ }^{2} / 4 \cdot \sigma_{m} \quad\left(a_{h} \text { : 主筋断面積 }\right) \\
& M_{p}=1 / 6 \cdot \phi_{h}{ }^{3} \cdot \sigma_{m} \quad\left(\phi_{h}: \text { 主筋径 }\right)
\end{aligned}
$$

と近似する。これは $N-M$ 曲線の $N=0.5 \cdot N_{\rho}$ の点と $N$ $=N_{p}$ の点を結んだ直線である。図一13 は $N-M$ 曲線の 精算值と略算値を比較したものであるが， $N>0.5 \cdot N_{p}$ の範囲では十分に適用可能である。また，鉄筋の応力度 は最大応力度 $\sigma_{m}$ を用いた。また, 図一12(b) のA点の モ一メント $M_{A}$ は, 鉛直荷重 $P$ と各带筋位置における

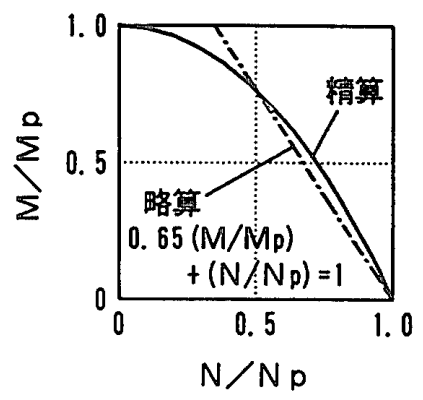

图一13 主筋の $M-N$ 関係のモデル化. 
横力 $Q$ が両端固定の柱に加わっているとして，

$$
\begin{aligned}
& M_{A}=P \cdot y_{B} / 2-1 / 24 \cdot Q \cdot S \cdot N_{B} \cdot f\left(N_{B}\right) \cdots \cdots \cdots(4) \\
& Q=a_{w e} \cdot \sigma_{w y} \\
& f\left(N_{B}\right)=\left(N_{B}{ }^{2}-1\right) / N_{B} \quad N_{B} \text { : 奇数 } \\
& \left(N_{B}{ }^{2}+2\right) / N_{B} \quad N_{B} \text { : 偶数 }
\end{aligned}
$$

で求められる。ここで， $a_{w e}$ は有効带筋断面積で 1 本の 帯筋断面積 $a_{w}$ とし， $\sigma_{w y}$ は帯筋降伏応力度である。こ のモーメントと軸力が式（3) を満たしているとし，さ らに式（2）を用いると（5) 式を得る。

$$
\frac{P}{N_{p}}=\frac{2 \cdot\left(\phi_{h} / S\right) \cdot}{3 \cdot N_{B} \cdot a_{x} \cdot \sqrt{\varepsilon_{B}}+2 \cdot\left(\phi_{h} / S\right)} \cdot g\left(N_{B}\right) \cdot
$$

ただし，

$$
g\left(N_{B}\right)=\left\{1+\frac{\pi \cdot a_{x} \cdot N_{B} \cdot f\left(N_{B}\right)}{16 \cdot\left(\phi_{h} / S\right)} \cdot \frac{a_{w e}}{a_{h}} \cdot \frac{\sigma_{w y}}{\sigma_{y}}\right\}
$$

である。

\section{3 座屈歪度 $\varepsilon_{B U C}$ の評価法}

文献 9，10）の方法は $\mathrm{C}$ 点の決定が複雑であり, 計 算に時間がかかる。そこで，本報告では3.節で示した 実験結果を用いて C 点を実験的に定めることを試みる。 まず，図一12(a) に示したように座屈歪度 $\varepsilon_{B U C}$ を降伏 棚までの跴度 $\varepsilon_{E R}$ と雨硬化開始点から潜在座屈点 $C$ 点ま での歪度 $\varepsilon_{H}$ およびD点から再び降伏応力度に達するま での F 点（座屈点）までの歪度 $\varepsilon_{B}$ に分割して考える。 ここで, $\varepsilon_{E R}$ は,

$$
\varepsilon_{E R}=10 \cdot \varepsilon_{y} \cdots
$$

とする。また， $\varepsilon_{B}$ は式 $(5)$ において $P=N_{y}\left(=\sigma_{y} \cdot a_{h}\right)$ を代入して求められるが, $N_{B}$ が未知数なので $N_{B}$ の関 数となり $\varepsilon_{B}\left(N_{B}\right)$ と表記し;

$$
\varepsilon_{B}\left(N_{B}\right)=\left[\frac{2 \cdot\left(\phi_{h} / S\right)}{3 \cdot N_{B} \cdot a_{x}}\left\{\frac{N_{\rho}}{N_{y}} \cdot g\left(N_{B}\right)-1\right\}\right]^{2} \cdot
$$

となる。(記号は前述)

次に $\varepsilon_{H}$ であるが，C点はそのときの瞬間剛性を用い て計算するオイラ一座屈応力度に依存し, また, 瞬間剛 性はそのときの軸歪度 $\varepsilon_{H}$ に依存する。したがって, 基 本となる弾性時のオイラ一座屈応力度 $\sigma_{c r}$ が大きいほ ど， $\varepsilon_{H}$ が大きくなることが推測される。そこで，表一3 に示されている $\varepsilon_{B U C}$ の実験值から式 $(6)(7)$ で与え られる $\varepsilon_{E R}$ と $\varepsilon_{B}\left(N_{B}\right)$ を引いたものを実験値より得られ た $\varepsilon_{H}$ として横軸にとり, 縦軸に弾性時のオイラー座屈 応力度 $\sigma_{c r}$ をとって図一14 に示す（図の横軸は micro 表示)。ただし, 式 $(7)$ で必要な座屈区間 $N_{B}$ は表一3 で示した実験値を用いた。結果は明らかな右上がりの傾 向が認められた。また，参考のために tangent modulus theory $と$ double modulus theory で求められた関係も

\begin{tabular}{|c|c|c|c|c|}
\hline & \multicolumn{3}{|c|}{ 主 筋 $の$ 配 筋 法 } \\
\hline & & $4-D 16$ & $4-\mathrm{D} 13$ & $4-\mathrm{D} i 0$ \\
\hline 帯 & $2-D 10-\$ 93$ & 222000 (1) & 130000 (1) & $57600 \quad(1)$ \\
\hline 筋 & 2-D6-S70 & $28300(3)$ & $54900(2)$ & $61400(2)$ \\
\hline の & 2-D6-S47 & $42800(4)$ & 49400 & $53400 \quad(3)$ \\
\hline 配 & $2-D 6-\$ 35$ & $55300(5)$ & 76000 (4) & $72200 \quad(3)$ \\
\hline 筋 & $2-\phi 4-S 47$ & 33200 (5) & $41700 \quad(3)$ & $39800 \quad(3)$ \\
\hline 法 & $2-\phi 4-S 35$ & $43300 \quad(6)$ & $48800 \quad(5)$ & $57800 \quad(3)$ \\
\hline & $2-\phi 4-523$ & $73100 \quad(7)$ & $85200(6)$ & $81200 \quad(5)$ \\
\hline
\end{tabular}
同図中に示した。理諭値が上回っているが，この関係が ほぼ直線で表せることが分かる。そこで, 奏験値を直線 で最小自乗法で推定したのが図中の直線であり， $\varepsilon_{H}$ の 評価式（8）となる。

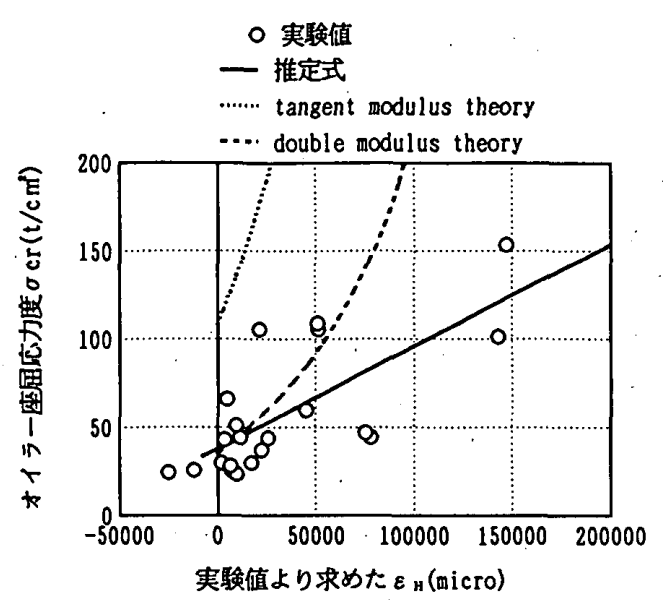

図一14 $\varepsilon_{H}$ とオイラー座屈忘力度 $\sigma_{c r}$ の関係

表一4 一方向実験シリーズの座屈歪度の計算値

$$
\varepsilon_{H}=0.00173 \cdot \sigma_{c r}-0.0661 \quad(\geqq 0) \cdot
$$

$\left(\sigma_{c r}\right.$ の単位は $\left.t / \mathrm{cm}^{2}\right)$

なお， $\sigma_{c r}$ は以下の式で与えられる。

$$
\sigma_{c r}=\frac{\pi^{2} \cdot E_{s} \cdot \phi h^{2}}{16 \cdot\left(N_{B} \cdot S / 2\right)^{2}}
$$

以上より, 座屈区間 $N_{B}$ の座屈歪度 $\varepsilon_{B U C}\left(N_{B}\right)$ は式 $(6)$ 〜 (8) を用いて,

$$
\varepsilon_{B U C}\left(N_{B}\right)=\varepsilon_{E R}+\varepsilon_{H}+\varepsilon_{B}\left(N_{B}\right)
$$

となり，可能な $N_{B}$ を用いて計算した $\varepsilon_{B U C}\left(N_{B}\right)$ の最小 值が座屈歪度 $\varepsilon_{B U C}$ の計算值となる。

表一4 は表一3 と同じスタイルで式（9）で与えられ る各試験体の $\varepsilon_{B U C}$ の計算值とそのときの $N_{B}$ の值を示し たものである。なお，可能な最大 $N_{B}$ (自然数) は断面せ いDを帯筋間隔 Sで除した值と実験值の $N_{B}$ の大きいほ うとした。ここで，可能な最大 $N_{B}$ とはカバーコンクリー 卜が損傷を受け主筋を拘束する効果がない領域（いわゆ る破壊領域)で生じうる座屈の最大区間数であり，この 領域の長さは一般的には断面せいD前後となる。しかし， この長さは帯筋の配筋方法によっても変化し, 本実験で も座屈長さが D を超えたものもあった。そこで，これら の試験体については実験で確認された座屈区間数まで許 容した。なお，破壊領域の長さが带筋量を反映して定量 的に評価された場合にはこの長さを用いた最大座屈区間 $N_{B}$ に統一すべきであろう。

図一15 は $\varepsilon_{B u c}$ の実験値と計算值を比較したものであ 


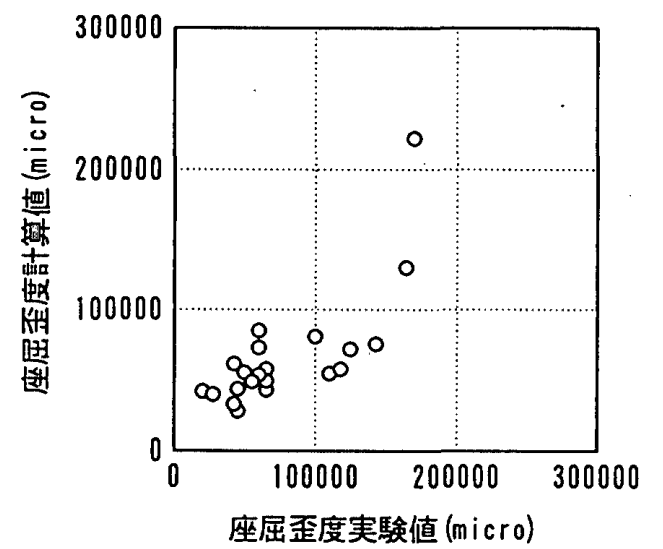

図一15㭫屈時䄳度の実験と計算の比較

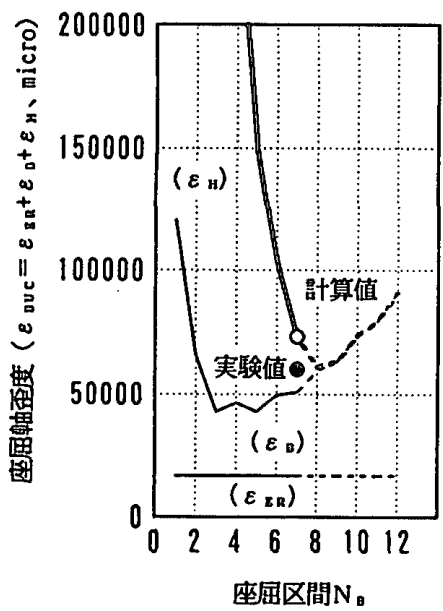

(a) $4 \mathrm{D} 16 \phi 4 \mathrm{~S} 23$

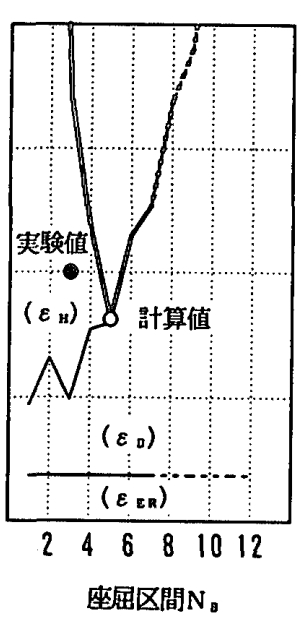

(b) $4 \mathrm{D} 10 \phi 4 \mathrm{~S} 23$
図一16座屈区間の座屈軸歪度への影響と実例

るが，計算値は実験值を大略推定している。また，図一 16(a)(b) は $N_{B}$ によって $\varepsilon_{B U C}$ がざう変化するかを図示 したもので，帯筋に $\phi 4$ を用いて $(S=23 \mathrm{~mm})$ 主筋が

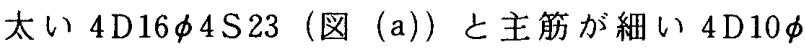
$4 \mathrm{~S} 23$ (図 (b)) について示した。因は太い実線が $\varepsilon_{B U C}$ を表し，さらに， $\varepsilon_{E R} ， \varepsilon_{H}$ および $\varepsilon_{B}$ の分類もしてある。 両試験体とも可能な $N_{B}$ は 7 であるが, 参考のため $N_{B}$ $=12$ まで破線で示してある。可能 $N_{B}$ での最小値が計算 值となるがこの点に○をつけ，実験值はすで示した。な お， $\varepsilon_{B}$ は $N_{B}$ の関数である $f\left(N_{B}\right)$ が偶数と奇数で異なっ た式となるので，やや凹凸のある曲線となる。

主筋が細い図 (b) の場合には計算値は $N_{B}=5$ が最小 となりここが計算値になるが，主筋が太い図（a）の場 合には計算値は可能 $N_{B}$ の最大値 7 で座屈形態が決まっ ており健全な非破壊コンクリートにより拘束されて座屈 長さが決まったとも考えられる。破壊領域がさらに長く なりうる試験体寸法・加力方法で行えば， $N_{B}$ はさらに 大きくなることも考えられる。

\section{5. まとめ}

（1）主筋の座屈性状に対する繰返し荷重の影響を検討
することを目的に，同一の配筋を持つ角柱試験体の単調 と繰り返しの載荷実験を行った。その結果, 主筋の応力 度-昰度関係は, 圧縮加力時の軸方向歪度をサイクル順 に加算した累積歪度が単調載荷時の座屈歪度と等しく なった点で座屈するモデルで表現できた。

（2）主筋之带筋の配筋法を変えた単調軸圧縮実験を行 い, 座屈時の軸歪度を求めた。主筋の負担応力度は主筋 の有無のみ異なる試験体の差より求めた。また，測定区 間での平均軸正度は座屈区間での軸昰度に修正してい る。

（3）帯筋より拘束された主筋の座屈時軸圣度 $\varepsilon_{B U C}$ の 概念を簡単なモデルに立脚し提案した。また，棒験結果 を用いて座屈軸歪度推定式 $\varepsilon_{B U C}\left(N_{B}\right)$ を求めた (本文 $(9)$ 式）。式（9）は座屈区間 $N_{B}$ の関数となるので, 可能 な $N_{B}$ を用いて計算した $\varepsilon_{B U C}\left(N_{B}\right)$ の最小值が $\varepsilon_{B U C}$ の計 算値となる。

\section{謝 辞}

本研究の実験およびデー夕解析を行うに当たり，金谷 淳二氏（東京電力, 当時新潟大学大学院生）を中心に新 潟大学卒研生に多大なる御協力をいただきました。ここ に，関係各位に謝意を表します。

\section{参考文献}

1）丸山久一, 清水敬二ほか 1 名： $\mathrm{RC}$ 柱の主筋座屈に関す る基礎的研究，コンクリート構造物の靶性と配筋方法に 関するシンポジウム論文集, 日本コンクリート工学協会, pp. $47 \sim 60,1990$ 年

2) 井上 晋, 塚田耕司, 宮川豊章, 藤井 学: $\mathrm{RC}$ 角柱供 試体の主筋座屈に関する実験的検討, 第 13 回コンクリー 卜工学年次論文報告集, pp. 333 338, 1991 年

3）神保善行, 山口善史, 中塚佶, 鈴木計夫ほか 1 名: コ ンファインドコンクリート内に配置された圧縮軸筋の座 屈時ひすみ（その1．実験概要および実験結果，その 2. 座屈時ひずみ推定式の誘導), 日本建築学会大会: 学術講演 梗概集，pp. 509 512，1991 年

4）広沢雅也ほか 2 名：鉄筋コンクリート短柱の崩壊防止に 関する総合研究 (その $21 ：$ 主筋の座屈), 日本建築学会 大会学術講演梗概集, pp. 1329 1330, 昭和 49 年

5）広沢雅也ほか 1 名：鉄筋コンクリート短柱の崩環防止に 関する総合研究 (その 30 : 主筋の座屈), 日本建築学会 大会学術講演梗概集, pp. 1127 1128, 昭和 50 年

6）島 弘ほか 3 名： RC 橋脚における主鉄筋座屈と勒性 に及ぼす带鉄筋配置の影響，コンクリート構造物の靶性 と配筋方法に関するシンポジウム論文集, 日本コンクリー 卜工学協会, pp. 33 40, 1990 年

7）矢代秀雄, 清水庸介：RC ばりの圧縮側に用いる異形棒 鋼の圧縮実験,第 13 回コンクリート工学年次論文報告集, pp. $269 \sim 274,1991$ 年

8）畑中重光ほか 2 名： $\mathrm{RC}$ 梁の終局域における压縮筋の座 屈に関する一考察, 第 13 回コンクリート工学年次論文報 告集, pp. 275 280, 1991 年

9）加藤大介，金谷渟二：鉄筋コンクリート造角柱の主筋の 
座屈性状の評価に関する研究, 第 12 回コンクリート工学 年次論文報告集, pp. 433 438, 1990 年

10）加藤大介, 金谷㳯二：鉄筋コンクリート部材の主筋の座 屈防止筋の評洒法に関する研究, コンクリート構造物の 靶性と配筋方法に関するシンポジウム論文集, 日本コン クリート工学協会, pp. $41 \sim 46,1990$ 年

11）加藤大介, 金谷淳二：繰返し加力を受ける $\mathrm{RC}$ 造柱の主
筋の坐屈性状の評価に関する実験的研究，第 13 回コンク リート工学年次論文報告集 $13-2$, pp. 369-374，1991 年

12）中低層鉄骨建物の耐震設計法, 社団法人鋼材俱楽部, 中 低層鋼構造骨組耐震性研究委員会編, 技報堂出版

(1991 年 11 月 29 日原稿受理, 1992 年 4 月 1 日採用決定) 